\title{
Style narodowe - architektura między apoteozą narodu a akceptacją współistnienia wspólnoty narodów
}

\section{National styles - architecture constructed between the apotheosis of a nation and acceptance of the co-existence of a community of nations}

\begin{abstract}
Streszczenie
Fenomen stylów narodowych jako konstruktów kulturowych można rozpatrywać w kontekście teorii „tradycji wynalezionej" autorstwa Erica Hobsbawma. Zasadą tej teorii jest w uproszczeniu tworzenie wymyślonych, do pewnego stopnia fikcyjnych tradycji, opartych jednak na zasadach autentycznych, istniejących. Budowle wznoszone w stylu narodowym miały tworzyć jednolitą przestrzeń nasyconą pierwiastkami narodowymi. Celem tej architektonicznej ideologii była apoteoza narodu. W obecnych czasach fenomen stylów narodowych uległ całkowitemu zanikowi. Nie wznosi się nowych obiektów w tych stylach. Natomiast percepcja zachowanych dzieł architektury w stylu narodowym przeszła ewolucję. Obecnie odbiera sie je jako obiekty o zróżnicowanym stylistycznie wystroju.
\end{abstract}

Słowa kluczowe: styl narodowy w architekturze, styl zakopiański, tradycja wynaleziona, pluralizm w architekturze

\begin{abstract}
The phenomenon of national styles as cultural constructs can be seen in the context of the theory of 'tradition invented' by Eric Hobsbawm. The basis of this theory is the simplification of the creation of imaginary and, to some extent, fictitious traditions but based on authentic, existing principles. Buildings erected in the national style were intended to create a uniform space saturated with national elements. The aim of this architectural ideology was the apotheosis of the nation. Nowadays, the phenomenon of national styles has completely disappeared. No new objects are erected in these styles. However, the perception of the preserved works of architecture in the national style has evolved. There are now perceived as objects with stylistically diverse decor.
\end{abstract}

Keywords: national style in architecture, Zakopane style, invented tradition, pluralism in architecture 


\section{STYL NARODOWY JAKO PRZYKŁAD TRADYCJI WYNALEZIONEJ}

Powstanie stylu zakopiańskiego i jego funkcjonowanie nie było zjawiskiem odosobnionym. Style narodowe tworzono wówczas w wielu krajach. Celem była intensyfikacja świadomości narodowej. W XIX wieku główną metodą intensyfikacji świadomości narodowej stało się odwoływanie do historii. XIX wiek był czasem zafascynowania historią zwaną dziejowością, w niemieckim wydaniu określaną jako Geschichtigkeit, we francuskim historicité. Epoka ta zyskała nawet miano „wieku historii".

Budowle wznoszone w stylu narodowym miały tworzyć jednolitą przestrzeń nasyconą pierwiastkami narodowymi. Należy pamiętać, że wiek XIX był wiekiem imperializmów - rozwoju wielkich imperiów. Style narodowe podkreślały w przestrzeni architektonicznej dominację mocarstw. Jako reakcja na to zjawisko zaczęły się wyłaniać style narodowe w krajach zależnych.

Dążenie do kreacji stylów narodowych powiązane jest z historyzmem i kulturową teorią narodu. Za prekursora historyzmu uważa się Johanna Gottfrieda Herdera. W dziele Myśli o filozofii dziejów (1785-92) przedstawił teorię narodu, według której głównym czynnikiem konstytuującym go jest kultura. Ważnym elementem kultury identyfikującym naród może stać się architektura. Koncepcja stylu narodowego wzmacnia i ukierunkowuje, ale też instrumentalizuje architekturę jako element określający tożsamość narodową.

Interesującym zjawiskiem była proliferacja stylów narodowych. W ramach jednego kraju (bądź ziem krajów zależnych) dochodziło do wykształcenia wielu stylów narodowych. W dodatku spektrum autentycznych stylów historycznych, do których się odwoływano, było zdumiewająco szerokie. W przypadku niemieckich stylów narodowych obejmowało tak odległe style jak styl romański i renesans. Dowodzi to pewnej sztuczności całej koncepcji. Zjawisko rozwoju stylów narodowych może być wyjaśniane na podstawie teorii „tradycji wynalezionej" brytyjskiego historyka Erica Hobsbawma. Teorię tę przedstawił Hobsbawm w napisanej wspólnie z Terence'em Rangerem książce Tradycja wynaleziona ${ }^{1}$.

Autorzy analizują na licznych przykładach zasady tworzenia wymyślonych, do pewnego stopnia fikcyjnych tradycji, ale jednak opartych o zasady istniejących, autentycznych. Eric Hobsbawm następująco opisuje tradycję wymyśloną:

Tradycja wymyślona oznacza zatem zespół działań o charakterze rytualnym lub symbolicznym, rzqdzonych zazwyczaj przez jawnie bqdź milczq̨o przyjęte reguły; działania te maja wpajać ludziom pewne wartości i normy zachowania przez ciqgłe repetycje - co siłq rzeczy sugeruje kontynuowanie przeszłości. W istocie tam, gdzie to jest możliwie, owe działania dq̨żq zwykle do ustanowienia więzi z odpowiadajqcym im czasem minionym².

Tkwi w tym pewien paradoks - zasada skonstruowana jest w sposób sprawiający wrażenie autentycznej, będąc w istocie rzeczy wtórną, „wymyśloną”. Po drugie jest wymyślona, ale jednak, jak wspomniano, na podstawie istniejących tradycji, stanowiąc niejednokrotnie 
ich rozwinięcie bądź wyolbrzymienie. Do pewnego stopnia mamy więc do czynienia z zatarciem granicy pomiędzy autentycznością i swego rodzaju fikcją „wymyślenia”, czy też „wynalezienia” tradycji. Zasada tradycji „,wynalezionej/wymyślonej” pierwotnie dotyczyła zagadnień społecznych. Sądzę, że teorię „tradycji wynalezionej” można zastosować do analizy dzieł architektonicznych i urbanistycznych. Wspomina o tym sam Eric Hobsbawm, pisząc m.in. o wyborze stylu gotyckiego (neogotyckiego) przy przebudowie parlamentu brytyjskiego w XIX wieku. Wątek architektoniczny jest jednak potraktowany w jego dziele w sposób marginalny.

\section{CZYNNIKI KULTUROWE WPŁYWAJĄCE NA INTENSYFIKACJĘ ZAINTERESOWANIA STYLAMI NARODOWYMI}

Fenomen stylów narodowych wywodzi się z Niemiec. Polskie style narodowe powstawały jako reakcja na style niemieckie. Metodologia konstruowania stylów - na podstawie arbitralnie dobieranych katalogów form detali historycznych - była wzorowana na metodologii architektów niemieckich. Oczywiście same detale oraz treści symboliczne związane były z architekturą polską. Wydaje się godnym uwagi prześledzenie, jakie czynniki wpłynęły w końcu XIX wieku na intensyfikację zainteresowania problematyką narodową w Niemczech oraz kreacji stylu narodowego w architekturze.

Czynnikiem, który w pośredni sposób przyczynił się do rozwoju stylów narodowych w Niemczech, było dążenie do skonsolidowania wspólnoty etnicznej narodu. Niemcy przed zjednoczeniem w roku 1871 w ramach Cesarstwa Niemieckiego żyli w wielu odrębnych państwach. O problemach związanych z kreacją skonsolidowanej wspólnej tożsamości pisze m.in. Reinhart Koselleck w artykule pt. Niemcy - spóźniony naród?:

Przypomnijmy, że pojęcie jednego narodu niemieckiego - pomijajq̨c pionierów humanistycznej literatury około 1500 roku - dopiero ukształtowało się powoli w ciqgu XVIII wieku i że to pojęcie jeszcze w XIX wieku było pojęciem wyrażajq̨cym oczekiwanie i nadzieję, któremu nie odpowiadał jeszcze żaden realny ustrój polityczny, aż do ustanowienia tzw. Rzeszy małoniemieckiej, która z nowego tworu państwowego wykluczała około jednq trzeciq Niemców. Empirycznie nie było więc jednego narodu niemieckiego, ale zawsze chodziło o wiele ludów, które wprawdzie mówiły podobnymi językami, dbały o łączq̨a je kulturę, ale politycznie były podzielone na liczne państwa terytorialne. Około 1800 roku bardzo poprawne określenie brzmiało "narodowości niemieckie” (deutsche Völkerschaft). To pojęcie obejmowało zarówno wielość poszczególnych ludów - Prusaków, Sasów, Bawarczyków, Austriaków itp. -jak też ich minimalne wspólnoty na urodzajnych polach kultury wspólnego języka literackiego³.

Drugim czynnikiem w sposób pośredni przyczyniającym się do rozwoju stylów narodowych był syndrom poczucia względnie niskiej wartości (ówczesnej) kultury niemieckiej opisany m.in. przez Friedricha Nietzschego w Niewczesnych rozważaniach (1873-76) Stwierdza filozof m.in.: 
Gdy mowa o zwycięstwie niemieckiego wykształcenia i kultury, jest to pomyłka biorq̨ca się stąd, że w Niemczech zagubiono czyste pojęcie kultury.

Kultura to przede wszystkim jedność artystycznego stylu we wszystkich przejawach życia danego narodu. Wiedza i uczoność zaś nie sq ani niezbędnymi środkami kultury, ani oznakami tejże, a w razie potrzeby godzq się doskonale z przeciwieństwem kultury, z barbarzyństwem, to jest z bezstylowościq albo z chaotycznym pomieszaniem wszystkich stylów.

Otóż w takim chaotycznym pomieszaniu wszystkich stylów żyje dziś Niemiec; i to doprawdy niebagatelny problem, jak też mu się udaje, przy całej uczoności, tego nie zauważać, a w dodatku szczerze cieszyć się swym dzisiejszym „wykształceniem”.

Druga połowa XIX wieku była czasem zwycięstw militarnych i politycznych Prus, zakończonych zjednoczeniem Niemiec i proklamowaniem Cesarstwa Niemieckiego w 1871 r. Idea stylów narodowych (a właściwie stylu narodowego w różnych odmianach) miała być ich dopełnieniem w płaszczyźnie kultury. Budowle w stylu narodowym powstawały na terenie ziem niemieckich, w tym również na obszarach zależnych, będących niegdyś ziemiami polskimi (które ostatecznie do Polski powróciły). Jako obiekty konsolidujące niemiecką etniczną wspólnotę narodową stały się w tym przypadku instrumentem przemocy symbolicznej.

Style narodowe polskie: styl zakopiański, wiślano-bałtycki, nadwiślański, zygmuntowski i dworkowy zostały skonfrontowane ze stylami narodowymi niemieckimi. Były nimi: neogotyk, neorenesans, neoromanizm (najwybitniejszym architektem działającym w tym stylu był Franz Schwechten), neobarok oraz Rundbogenstil (styl okrągło-łukowy, arkadowy).

Konfrontacja pomiędzy polskimi stylami narodowymi i stylami niemieckimi miała na ogół charakter pośredni. Władze zaborcze dążyły do stworzenia jednolitej przestrzeni symbolicznej nasyconej pierwiastkami narodowymi. Przestrzeń niegdyś należąca do państwa polskiego miała być zawłaszczana, niezależnie od działań politycznych, również poprzez działania architektoniczne. Działania takie były odczytywane jako „przemoc symboliczna”. Polscy architekci, działacze niepodległościowi, księża próbowali, o ile było to możliwe, kształtować enklawy przestrzeni o polskiej tożsamości. Wykorzystywane były zwłaszcza możliwości budowy polskich kościołów.

Należy w tym miejscu przypomnieć, że lawinowy wzrost nastrojów nacjonalistycznych, którego symptomem było zainteresowanie się stylami narodowymi, był jedną z przyczyn wybuchu I wojny światowej. Rozczarowanie i rozgoryczenie Niemców po przegranej wojnie w 1918 r. stało się z kolei jedną z przyczyn wybuchu II wojny światowej. Kataklizm wywołany przez obydwie wojny przyczynił się do definitywnego zaniku idei stylów narodowych w architekturze.

\section{DZIEDZICTWO STYLÓW NARODOWYCH}

W okresie dwudziestolecia międzywojennego po epoce fascynacji historią doszło do prób ograniczenia, a nawet wyparcia świadomości historycznej w kulturze. W okresie tym osłabieniu uległa potrzeba wyrazistego podkreślania tożsamości narodowej w architekturze. 
Nastąpił kres fenomenu stylów narodowych. (Oczywiście w krajach totalitarnych jak III Rzesza kultywowano określoną formę stylu narodowego). Można wymienić dwie główne przyczyny tego zwrotu.

Pierwszą przyczyną schyłku fenomenu stylów narodowych były zjawiska polityczne. W wyniku I wojny światowej doszło do rozpadu wielkich imperiów, a państwa zależne odzyskały niepodległość. Zanikła potrzeba swoistej legitymizacji narodowej mocarstw poprzez kreację jednolitej przestrzeni symbolicznej. Jednocześnie zakończyła się epoka stosowania swoistej „symbolicznej przemocy” wobec zależnych do niedawna krajów. Owa „symboliczna przemoc" polegała na wznoszeniu budowli w stylach narodowych. W państwach, które odzyskały niepodległość do pewnego stopnia, zbędna stała się potrzeba ostentacyjnego i wyrazistego podkreślania tożsamości narodowej w sztuce.

Drugą przyczyną schyłku idei stylów narodowych były przemiany w sztuce i kulturze. W okresie poprzedzającym I wojnę światową i przede wszystkim po niej nastąpił zwrot kulturowy w kierunku wartości uniwersalnych i kosmopolitycznych. W architekturze egzemplifikacją tych tendencji stał się styl międzynarodowy.

Percepcja fenomenu stylów narodowych przeszła swoistą ewolucję: od afirmacji poprzez gwałtowną krytykę i falę szyderstw do krytycznej akceptacji. Na terenie Polski znalazły się budynki reprezentujące style narodowe imperiów, pod których zaborami pozostawały ziemie polskie, a z drugiej strony - budowle wzniesione w polskich stylach narodowych. Ocena dziedzictwa fenomenu stylów narodowych jest niejednoznaczna. Architektura budowli wykonanych w konwencji owych stylów była na ogół wtórna. Operowała, jak wspomniano, katalogiem form i cytatów dobranych z autentycznych budynków historycznych na ogół w arbitralny sposób. Natomiast można wyróżnić trzy aspekty pozytywne dziedzictwa architektury stylów narodowych.

Pierwszą cechą pozytywną jest pluralizm form architektonicznych uzyskany dzięki zaistnieniu na ziemiach polskich dwóch zasadniczych kategorii stylów, pierwotnie pozostających ze sobą w stanie konfrontacji. Wspomniana wyżej proliferacja stylów narodowych w ramach poszczególnych kategorii dodatkowo poszerza spektrum różnorodności stylistycznej.

Drugą cechą pozytywną jest zatarcie w sferze percepcji intencjonalnie narodowego charakteru budynków. Z perspektywy historii intencja architekta, by zaprojektować budynek w stylu narodowym, stała się nieczytelna. Na ogół nikt we współczesnych czasach nie identyfikuje np. gmachu Zamku Cesarskiego w Poznaniu jako obiektu wybudowanego w narodowym stylu niemieckim. Z drugiej strony niewiele osób identyfikuje kościołów zaprojektowanych przez Jana Sasa-Zubrzyckiego jako budowli wniesionych w stylu nadwiślańskim - narodowym stylu polskim. Pewnego rodzaju słabość metody kreacji stylów narodowych, polegająca na arbitralnym doborze form historycznych, okazała się paradoksalnie w perspektywie historycznej mocną stroną. Charakter architektury okazał się wbrew zamierzeniom twórców uniwersalny. Wszystkie budowle, projektowane niegdyś jako obiekty w stylach narodowych, wrosły we współczesny uniwersalny, zglobalizowany krajobraz i wzbogacają go. 
Jedynym chyba wyjątkiem było rozebranie wspomnianej uprzednio cerkwi św. Aleksandra Newskiego wzniesionej na placu Saskim w Warszawie. Budowla ta została zaprojektowana w wystroju typowej cerkwi rosyjskiej w reprezentacyjnym punkcie Warszawy.

Trzecią cechą jest oddziaływanie urbanistyczne i krajobrazowe obiektów tworzonych w stylach narodowych. Przykładem oddziaływania urbanistycznego są neogotyckie kościoły w stylu nadwiślańskim projektowane przez Jana Sasa-Zubrzyckiego. Małe, prowincjonalne, na wpół wiejskie miasta, w których zostały one wzniesione (Sokołów Małopolski, Błażowa, Ciężkowice itd.), otrzymały widoczną z daleka dominantę w postaci obiektu sakralnego z wieżą lub wieżami, której w takim kształcie nigdy nie posiadały. W ten sposób kreowano nową „skonstruowaną" sylwetę miasta. Sasowi-Zubrzyckiemu udało się osiągnąć efekt nobilitacji urbanistycznej małych miast. Sas-Zubrzycki jest również autorem trzech obiektów w Jordanowie, tworzących swego rodzaju założenie urbanistyczne w stylu nadwiślańskim. Obiektami tymi są: kościół, ratusz i dawny sąd grodzki. Budowle zlokalizowane przy rynku i w jego sąsiedztwie podnoszą prestiż małego miasta.

Przykładem oddziaływania urbanistycznego związanego z narzucaniem Polsce innych stylów narodowych był np. plan urbanistyczny niemieckiego architekta Josepha Stübbena dla Dzielnicy Cesarskiej w Poznaniu. Dominantą dzielnicy był oczywiście Zamek Cesarski projektowany przez Franza Schwechtena w stylu narodowym neoromańskim jako siedziba cesarza Wilhelma II. Dzielnicę cechowały dwa oblicza. Z jednej strony została bardzo nowatorsko, z rozmachem zaprojektowana i miała zmienić Poznań w nowoczesne miasto. Z drugiej strony jej celem było zniewolenie ludności polskiej. Obecnie, po usunięciu funkcji opresyjnych, Zamek Cesarski służy jako Centrum Kultury, a położony nieopodal budynek złowrogiej dla Polaków Komisji Kolonizacyjnej jest siedzibą jednej z poznańskich uczelni. Dzięki ponadczasowej urbanistyce i architekturze, która wbrew zamierzeniom twórców okazała się uniwersalna, dzielnica stała się centrum kulturalnym i usługowym Poznania.

Historia dopisała niespodziewany epilog do dziejów projektowanego przez Franza Schwechtena w stylu neoromańskim kościoła Kaiser-Wilhelm-Gedächtniskirche w Berlinie. Kościół został zbombardowany przez lotnictwo alianckie w czasie II wojny światowej w roku 1943. (Jednocześnie zniszczono otaczającą go zabudowę również utrzymaną w stylu neoromańskim). Po wojnie władze ówczesnego Berlina Zachodniego postanowiły nie odbudowywać świątyni. Pozostawiono ruinę głównej wieży kościoła (o wysokości 68 m), do której dobudowano ośmiokątną nawę, sześciokątną dzwonnicę, czworokątną kaplicę i kruchtę. Autorem ukończonej w 1961 roku przebudowy był architekt Egon Eiermann. W 1987 roku w kościele zainstalowano krzyż wykuty z żelaza pochodzącego z więźby katedry św. Michała w Coventry zburzonej w nalocie lotnictwa niemieckiego w 1940 roku. Powstał w ten sposób architektoniczny symbol pokoju i pojednania. 


\section{SZCZEGÓLNE ZNACZENIE DZIEDZICTWA STYLU ZAKOPIAŃSKIEGO. WIELOWYMIAROWOŚĆ STYLU ZAKOPIAŃSKIEGO JAKO ZJAWISKA KULTUROWEGO}

Styl zakopiański można określić jako wielowymiarowe zjawisko kulturowe. Głównym jego elementem był proces kreacji stylu narodowego w architekturze na podstawie elementów sztuki ludowej Podhala przez Stanisława Witkiewicza. Procesowi towarzyszyły działania artystyczne obejmujące architekturę wnętrz i wzornictwo - rzemiosło artystyczne. Podstawę teoretyczną stanowiły rozległe studia etnograficzne, których wynikiem były słynne tablice litograficzne zawarte w książce Budownictwo ludowe na Podhalu Władysława Matlakowskiego. Spektrum działań artystycznych obejmowało również literaturę i publicystykę: Stanisław Witkiewicz jest autorem prozy poetyckiej Na przełęczy. Dzięki szerokiemu spektrum działań artystycznych i naukowych Stanisławowi Witkiewiczowi i innym artystom oraz badaczom udało się wykreować, jak zauważa m.in. Barbara Tondos ${ }^{6}$, mit górali. Mit ów zresztą według badaczki do pewnego stopnia utrudnia obiektywne badania i ocenę fenomenu stylu zakopiańskiego.

Metodologia stylu zakopiańskiego zdecydowanie wpłynęła na kształt krajobrazu Podhala. W zasadzie nie powiodły się próby stworzenia stylu ogólnopolskiego na podstawie stylu zakopiańskiego. Trzeba w tym miejscu przypomnieć, że prawie wszystkie style narodowe pozostały w jakimś sensie „niedokończonymi” konstruktami kulturowymi. Natomiast w skali lokalnej styl zakopiański okazał się ponadczasowy. Do chwili obecnej stanowi wzorzec i układ odniesienia dla projektantów. W zasadzie jako jedyny styl aspirujący do stylu narodowego pozostał rozpoznawalny i funkcjonuje w polskiej kulturze. Warto zauważyć, że tylko styl zakopiański doczekał się tak wielu opracowań naukowych. Dla porównania twórczość Jana Sasa-Zubrzyckiego jeszcze do niedawna nie miała pełnego monograficznego opracowania. Ponadczasowość stylu zakopiańskiego wynika z omówionej uprzednio konsekwentnej i racjonalnej metodologii kreacji stylu Witkiewicza. Jako jedyny twórca stylu narodowego wybrał jako źródło inspiracji sztukę ludową.

W czasach współczesnych, w dobie globalizacji dominuje tendencja preferowania trendów uniwersalnych lub (w ich ramach) trendów regionalnych/wernakularnych. Przeważają poglądy, że w propagowaniu form architektury narodowej tkwi potencjalne niebezpieczeństwo kreacji form prowincjonalnych, zaściankowych. We współczesnej architekturze ewentualne cechy narodowe mogą powstawać spontanicznie, np. poprzez częste powtarzanie pewnych form na terenie kraju, używanie określonych materiałów, tworzenie szkół architektonicznych kultywujących szczególne kierunki.

Tradycja stylu zakopiańskiego funkcjonuje jako wielowymiarowe zjawisko kulturowe. Istnieje sprzężenie zwrotne między zmitologizowaną tradycją stylu i współczesnym środowiskiem górali podhalańskich. Styl został zinternalizowany przez środowisko, ale też do pewnego stopnia jego tradycja uległa deformacji. Tradycja wytworzona przez styl pomaga zachować tożsamość środowisku, z kolei środowisko kultywuje przekształcone zasady stylu zakopiańskiego. 
Sądzę, że współczesna tradycja stylu zakopiańskiego rozwija się na dwóch płaszczyznach. Jedną jest szeroki, popularny nurt powierzchownego zainteresowania stylem, kulturą i w ogóle rzeczywistością Podhala. Warto posłużyć się w tym miejscu pojęciem „zakopiańszczyzny”. Barbara Tondos opisuje w swojej książce Styl zakopiański i zakopiańszczyzna ową „zakopiańszczyznę” takimi słowami: „Zakopiańszczyzna, czyli nieokreślona chęć budowania "po zakopiańsku», pojawiła się w miastach i na wsiach, ubarwiając ich krajobraz. Obecnie przeżywa swoisty renesans"7. Niezależnie od „zakopiańszczyzny” rozwija się nurt fachowych badań nad kulturą regionu. Powstają projekty architektoniczne w twórczy sposób rozwijające ideę stylu zakopiańskiego, architektury regionalnej i architektury danego obszaru. Zakopane ciągle jest ważnym ośrodkiem sztuki w Polsce.

Paradoksalnie działania w obydwóch tych płaszczyznach przyczyniają się do wzrostu znaczenia Podhala. Jest ono jednym z niewielu regionów Polski o tak wyraźnie ukształtowanej tożsamości. Wielkie są w tym zasługi Stanisława Witkiewicza i wygranej w przeszłości konfrontacji jego koncepcji stylu zakopiańskiego ze „sposobem zakopańskim”. Być może we współczesnych czasach ambitne działania również przeważą nad zakopiańszczyzną.

\section{PRZYPISY}

1 Tradycja wynaleziona, red. E. Hobsbawm, T. Ranger, przeł. M. Godyń, F. Godyń, Wydawnictwo Uniwersytetu Jagiellońskiego, Kraków 2008.

2 Tamże, s. 10.

3 R. Koselleck, Warstwy czasu. Studia z metahistorii, przeł. K. Krzemieniowa, J. Merecki, Oficyna Naukowa, Warszawa 2012, s. 335.

4 F. Nietzsche, Narodziny tragedii. Niewczesne rozważania, tłum. P. Pieniążek, M. Łukasiewicz, Wydawnictwo Officyna, Łódź 2012, s. 185-189.

5 Tamże, s. 187-188.

6 B. Tondos, Styl zakopiański i zakopiańszczyzna, Zakład Narodowy im. Ossolińskich, Wrocław 2009.

7 Tamże, s. 192-193.

\section{BIBLIOGRAFIA}

Jabłońska T., Moździerz Z., „Koliba” Pierwszy dom w stylu zakopiańskim, Muzeum Tatrzańskie im. dra Tytusa Chałubińskiego, Zakopane 1994.

Koselleck R., Warstwy czasu. Studia z metahistorii, przeł. K. Krzemieniowa, J. Merecki, Oficyna Naukowa, Warszawa 2012.

Matlakowski W., Budownictwo ludowe na Podhalu, Akademia Umiejętności, Kraków 1892. 
Moździerz Z., Dom „Pod Jedlami” Pawlikowskich, Muzeum Tatrzańskie im. dra Tytusa Chałubińskiego, Zakopane 2003.

Nietzsche F., Narodziny tragedii. Niewczesne rozważania, tłum. P. Pieniążek, M. Łukasiewicz, Wydawnictwo Officyna, Łódź 2012.

Stefański K., Polska architektura sakralna w poszukiwaniu stylu narodowego, Wydawnictwo Uniwersytetu Łódzkiego, Łódź 2000.

Tondos B., Styl zakopiański i zakopiańszczyzna, Zakład Narodowy im. Ossolińskich, Wrocław 2009.

Tradycja wynaleziona, red. E. Hobsbawm, T. Ranger, przeł. M. Godyń, F. Godyń, Wydawnictwo Uniwersytetu Jagiellońskiego, Kraków 2008.

Witkiewicz S., Na przełęczy. Wrażenia i obrazy z Tatr, Gebethner i Wolff, Warszawa 1891.

Witkiewicz S., Wybór pism estetycznych, Towarzystwo Autorów i Wydawców Prac Naukowych Universitas, Kraków 2009.

Wowczak J., Jan Sas-Zubrzycki. Architekt, historyk i teoretyk architektury, Wyd. Towarzystwo Wydawnicze „Historia lagellonica”, Kraków 2017. 